\title{
Simple basic model for concrete and its application \\ Part 3. Factors affecting consistency, material balance equations and mix design
}

\author{
GyULA PEKÁR - private consultant - alba-qualit@hdsnet.hu \\ Érkezett: 2013. 06. 06. " Received: 06. 06. 2013. - http://dx.doi.org/10.14382/epitoanyag-jsbcm.2013.22
}

\begin{abstract}
During the plant observations a number of interesting questions arose concerning consistency. The manufacturing plants (or the sites where pre-mixed concrete is transported from) are the ideal place for carrying out investigations to gather a wealth of valuable data. Nevertheless, the statistical characteristics for consistency in no way demonstrate the same kind of close correlation as those for compressive strength or deformation, so there is justification in being cautious, even though being cautious should never prevent us from drawing certain conclusions. When designing the composition of fresh concrete mixes, it may be useful to incorporate the (structural) content indicators of the concrete composition, provided that we know (or conduct experiments to find out) the correlations between the concrete composition content indicators and the properties of the fresh and hardened concrete, and apply the material balance equations of concrete mixes. The final part in this series of papers focuses on these issues.
\end{abstract}

Gyula PEKÁR

Chemical engineer (University of Veszprém, 1981). Active in the construction industry since 1984 , first as a research engineer, and later as head of the laboratory at ARÉV, which was at the time the leading construction company in Székesfehérvár. From 2000, as a private consultant, he prepared enterprises for the implementation and operation of a number of QA systems (ISO 9001, ISO 14001, ISO/IEC 17025). From 2007-2013 he was a part-time engineering inspector at the state-owned ÉMI (Non-Profit Limited Liability Company for Quality Contro and Innovation in Building). With the support of ÉMI, he carried out a research project, originally in conjunction with the Augusztin Concrete Manufacturing Company (Zamárdi), to establish the correlations between concrete compositions and the performance indicators of the set concrete, by recording observations of concrete mixes during their manufacture at the mixing plant. In 2011, he was invited by the Hungarian Institute for Transport Sciences to participate in research into low-shrinkage floor concrete compositions.

\section{A brief review of the literature}

A knowledge of the factors that affect the consistency of fresh concrete is important for conscious planning of workability, and research has therefore long been conducted into this area. The work of Alexanderson is especially interesting because he has examined the different composition conditions under which constant consistency (consistency of the same class) can be provided, across a very broad range of mixes, from paste (mortar) mixes to concrete mixes [1]. The diagrams he published (see Figs. 27 and 28) express the principle that consistency could only remain constant when $d r y$ aggregates are added to a given cement paste of a known consistency if the water-cement ratio is simultaneously increased. The volumetric ratio of the aggregates in the concrete, however, can only be increased to a maximum limit, which also depends on consistency, roughly in line with Fig. 28. Alexanderson is remarkable in that he not only considers the air content of pastes (admixtures which form bubbles of air) and the impact they have on consistency, but he also calculates with it.

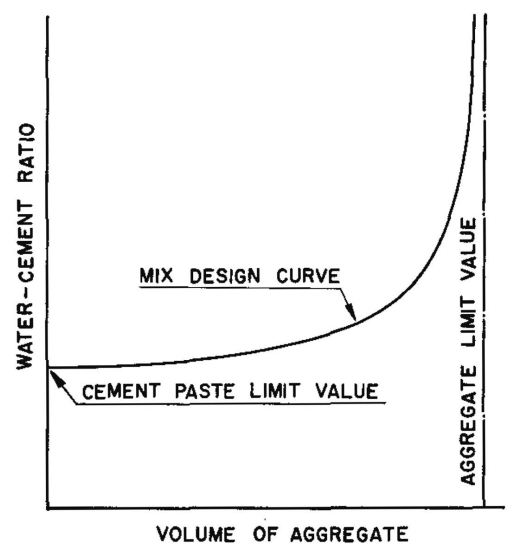

Fig. 27. Relationship between the percentage of aggregate by volume and the water/ cement ratio at constant consistency, after Alexanderson [1]

27. ábra Az azonos konzisztencia biztositásához szükséges $v / c$ tényezö változása a betonban levö adalékanyag térfogatarányának függvényében, Alexanderson szerint [1]

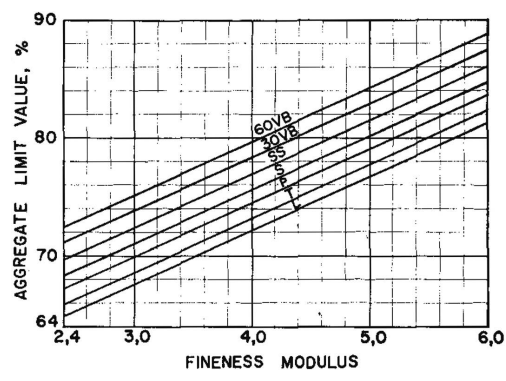

Fig. 28. Aggregate limit value for concrete made with natural coarse aggregate and air content 1.5-2.5 V\% (the Swedish designations for consistency classes are roughly in line with the scale of S1...S4 consistency classes)

28. ábra Az adalékanyag bedolgozható maximális térfogatarányának függése a finomsági modulustól, különböző konzisztencia-osztályok esetén (a svéd jelölések fentröl lefelé nagyjából az S1...S4 osztályoknak felelnek meg)

In Hungary, the work of Ujhelyi in mix design accounting for consistency is outstanding: his DSc thesis of 1989 [2] not only gives a thorough summary of the methods for estimating water demands, but also describes a new method for calculating consistency-dependent water demands. The method is suitable for the design of consistency of mixes without admixtures. In the proposed formulae the water demands of aggregates depend on the fineness modulus, and the water demands of cement depend on the specific surface area. The latter predicts the so-called surface aspect: it is noticed that not only the masses and volumes of the set of solid phase components are included in concrete mixes, but also their surface areas, and the surface areas may have particular influences on the properties of the concrete.

Design of consistency is complicated due to the presence of cements and additions which have high specific surface areas and by the effects of high range water reducing admixtures - which can produce special rheological phenomena. This is the reason behind the ever increasing number of articles published in the last decade that deal with observations of the rheological behaviour of cementitious mixes. In Hungary, Spránitz and his associates have examined the flow time and flow value of pastes made by different 
cements and admixtures, and have found numerical correlations between the rheological properties and the composition properties $[3,4]$. Their work was consciously directed towards the investigation of pastes, since (as Alexanderson also recognised) the rheological behaviour of concrete is determined to a great extent by the properties of the paste.

A source of inspiration for future research in Hungary could be provided by the report of Toutou and Roussel [5]. The authors examined the rheological behaviour of concrete constituents in four cumulative stages: firstly in suspensions (water + silica fume), secondly in pastes (water + silica fume + cement), thirdly in mortars (water + silica fume + cement + sand), and fourthly in concretes (water + silica fume + cement + sand + gravel). The rheological properties of all four types of mixes were investigated, and they reported interesting data concerning the correlations between shear stress and shear rate, and between yield stress and combined volumetric ratios of solid phase constituents. It would be worth pursuing this direction of research in Hungary too; it would not require unaffordable costs, but mainly systematic and perseverant work. The outcome would be more reliable mix design for concrete workability, particularly in the case of high performance concretes, which are more sensitive from a rheological point of view.

\section{Factors influencing consistency according to the simple basic model for concrete}

In the simple basic model, the influence of concrete composition content indicators is also a subject for analysis with regard to consistency and the rheological properties of fresh concrete ( $p$ : ratio of paste in the concrete, $x$ : volumetric ratio of liquid to paste powder, $\chi_{c}$ : volumetric ratio of cement in the paste powder, $\lambda_{A D}$ : volumetric ratio of admixtures to paste powder, l: volumetric ratio of air in the concrete), although the physical properties of concrete constituents must be considered at all times. For example, one such important influencing factor is the volumetric specific surface area of the combined solid phase matter (paste powder and aggregate particles) making up the concrete, which is calculated by the method described in [6]; which is essentially the procedure proposed by Kausay [7], with the difference that as standard the particles are considered to be not spherical, but ellipsoid in shape. The role of the surface area of materials included in concrete mixes is obvious, because during the flow of the concrete, the combined solid particles have a mutual effect on each other through their surface areas, and also have an effect on the fluid (water, which may also contain admixtures) that plays the role of dispersing agent.

Concrete is considered from a rheological point of view to be a self-affine (fractal-like) composite system, which manifests itself in the combined solid phase of constituents in dimensions of different scales showing a repeating structure. The cement + addition powder as dispersed phase plays the same role in paste as it is played by aggregate in concrete. Also, the fluid (mostly water), which is the dispersing agent in the paste plays the same role as it is played by the paste in concrete. Paste acts as the dispersing agent for the aggregate as the dispersed phase. The only substantial difference between the aforementioned dispersed phases lies in the 2 order of magnitude difference between their particle sizes, but the structure in the different magnitude scales is continuously repeated, which can presumably be traced back to the exponential distribution of the particle sizes of the combined solid phase constituents of concrete.

If the surface of the powder particles of the paste are covered in a thick layer of fluid (but naturally not so thick that they can bleed) then the paste can be expected to flow better than if the layer of fluid covering the particles is thinner. The same large-scale range of dimensions is still valid: if the surface of the aggregate is covered by a thick layer of paste (acting almost as a fluid) then the fresh concrete mix can be expected to flow better than in the case where the aggregate gets a thin layer of paste. From the point of view of fluidity, the consistency of the neat paste serves as the maximum threshold value (in this case the paste thickness is infinite), since when combined solid phase matter is added to the paste (either aggregate or paste powder) then the added surplus surface area dilutes the thickness of the dispersing agent covering the dispersed particles, causing a decreased fluidity of the mix.

The influence of water-reducing admixtures $\left(\lambda_{A D}>0\right)-$ following the above idea - can also be interpreted as diluting the thicknesses of the dispersing agent which would be necessary to achieve a given consistency in mixes without admixtures in every range of dimensions of the dispersed phase particles. In the case of the 132 batches of plastic consistency concrete mixes investigated during the plant observations detailed in [8] (of which 72 were made without admixtures, and 60 were made by water-reducing admixture), the average thickness of the paste (as dispersing agent) reaching the aggregates within the range of dimensions $\varnothing 0.063-32 \mathrm{~mm}$ was, significantly, several $\mu m$ thinner for mixes with admixtures than for mixes without admixtures. This paste diluting effect can actually represent savings in paste between 10 to 30 litres (depending on the type and characteristics of the aggregate) when applied to each cubic meter of mix.

If the mix composition of the concrete is known, then the thickness of a dispersing agent covering a $d$ sized particle in the dispersed phase can be calculated simply by Eqs. (37) and (38):

$$
\begin{aligned}
& \mathrm{t}_{a}=\frac{1}{2} \cdot \mathrm{d}_{a}\left(\left(1+\frac{p}{a}\right)^{\frac{1}{3}}-1\right) \\
& \mathrm{t}_{z}=\frac{1}{2} \cdot \mathrm{d}_{z}\left((1+x)^{\frac{1}{3}}-1\right)
\end{aligned}
$$

where:

$\mathrm{t}_{a}$ is the thickness [mm] of the layer of paste covering the aggregate particles of diameter $\mathrm{d}_{a}[\mathrm{~mm}]$,

$\mathrm{t}_{z}$ is the thickness $[\mu \mathrm{m}]$ of the layer of fluid (water) covering the paste powder particles of diameter $\mathrm{d}_{z}[\mu \mathrm{m}]$,

$p$ is the volumetric ratio of the paste in the concrete (concrete composition content indicator),

$a$ is the volumetric ratio of aggregate in the concrete $(a>0)$, and

$x$ is the volumetric ratio of fluid-paste powder. 


\begin{tabular}{|c|c|c|c|c|c|c|c|c|c|c|}
\hline & & \multicolumn{5}{|c|}{$\begin{array}{l}\text { Concrete composition (structural) } \\
\text { content indicators }\end{array}$} & \multicolumn{4}{|c|}{ Other technical data and information } \\
\hline & & $\mathbf{p}$ & $\mathbf{x}$ & $\chi_{c}$ & $\lambda_{A D}$ & $\mathbf{I}$ & $\begin{array}{l}\text { Admixtures included in } \\
\text { the evaluation* }\end{array}$ & $\begin{array}{l}\text { Traditional } \\
w / c \text { ratio }\end{array}$ & $a^{* *}$ & $\begin{array}{l}D_{\max } \\
\mathbf{m m}\end{array}$ \\
\hline \multirow{4}{*}{$\begin{array}{l}\text { Plant observations of } \\
\text { consistency } \\
2008-2010 \text {. } \\
242 \text { observations }\end{array}$} & $\min$ & 0.153 & 0.924 & 0.552 & 0.000 & 0.000 & \multirow{4}{*}{$\begin{array}{l}\text { High range water reducer } \\
\text { (HRWR) } \\
\text { Mid range water reducer } \\
\text { (MRWR) and } \\
3 \text { types of water reducers } \\
\text { (WR) }\end{array}$} & 0.335 & 0.652 & 4 \\
\hline & $\max$ & 0.314 & 3.381 & 0.977 & 0.030 & 0.088 & & 1.218 & 0.790 & 32 \\
\hline & average & 0.255 & 1.684 & 0.839 & 0.009 & 0.017 & & 0.685 & 0.728 & 24 \\
\hline & distribution & 0.021 & 0.301 & 0.080 & 0.009 & 0.014 & & 0.143 & 0.019 & 8 \\
\hline
\end{tabular}

Table 11. Concrete composition content indicators and other data for mixes subjected to consistency examinations during plant observations; ${ }^{*}$ Note: The product names of the admixtures have been omitted intentionally; ${ }^{* *}$ Note: $a$ : the volumetric ratio of aggregate in the concrete mix 11. táblázat Az üzemi megfigyelések során konzisztencia-vizsgálatoknak alávetett keverékek betonösszetételi állapotjelzői és egyéb adatai ( ${ }^{*}$ az adalékszerek termékmegnevezéseit szándékosan mellőzzük, ${ }^{* *} a$ : a betonkeverékben lévő adalékanyag térfogataránya)

\begin{tabular}{|c|c|c|c|c|c|c|c|c|c|c|c|c|}
\hline \multirow[b]{2}{*}{$\begin{array}{l}\text { Admixture } \\
\text { code name }\end{array}$} & \multirow[b]{2}{*}{$\begin{array}{c}\text { Number of } \\
\text { observations }\end{array}$} & \multicolumn{2}{|c|}{$\begin{array}{l}p \text { - paste volu- } \\
\text { metric ratio }\end{array}$} & \multicolumn{2}{|c|}{$\begin{array}{l}\mathrm{x} \text { - fluid-powder } \\
\text { volumetric ratio }\end{array}$} & \multicolumn{3}{|c|}{$\begin{array}{c}\lambda^{*} \text { - dose of admixture } \\
\text { as volumetric ratio of the } \\
\text { paste powder }\end{array}$} & \multicolumn{2}{|c|}{$\begin{array}{l}\text { Measured flow } \\
\text { values [mm] }\end{array}$} & \multicolumn{2}{|c|}{$\begin{array}{l}\text { Factors for Eq. } \\
\qquad(39)\end{array}$} \\
\hline & & $\mathbf{p}_{\min }$ & $\mathbf{p}_{\max }$ & $x_{\min }$ & $x_{\max }$ & $\lambda_{\min }$ & $\lambda_{\text {average }}$ & $\lambda_{\max }$ & flow $_{\text {min }}$ & flow $_{\max }$ & $f_{1, A D}$ & $f_{2, A D}$ \\
\hline without admixture & 113 & 0.153 & 0.302 & 1.254 & 3.381 & 0.000 & 0 & 0 & 300 & 470 & 1 & 1 \\
\hline HRWR & 49 & 0.220 & 0.267 & 1.287 & 1.675 & 0.010 & 0.014 & 0.025 & 390 & 550 & 14.256 & 1.004 \\
\hline MRWR & 10 & 0.212 & 0.314 & 0.924 & 1.872 & 0.008 & 0.016 & 0.030 & 340 & 590 & 8.868 & 1.012 \\
\hline WR-1 & 28 & 0.214 & 0.285 & 1.076 & 1.975 & 0.012 & 0.020 & 0.029 & 380 & 480 & 4.529 & 1.012 \\
\hline WR-2 & 31 & 0.217 & 0.290 & 1.297 & 1.876 & 0.006 & 0.016 & 0.028 & 350 & 480 & 4.846 & 1.017 \\
\hline WR-3 & 11 & 0.240 & 0.263 & 1.215 & 1.850 & 0.012 & 0.020 & 0.028 & 390 & 480 & 4.042 & 1.004 \\
\hline
\end{tabular}

Table 12. Data concerning the concrete composition content indicators and consistency values for mixes made with and without different types of admixture, and the factors $f_{1, A D}$ and $f_{2, A D}$ of Eq. (39)

12. táblázat Az adalékszer nélküli és a különbözö adalékszerekkel megvalósult keverékek betonösszetételi állapotjelzöinek és konzisztencia mértékszámainak adatai, valamint a (39) képlet $f_{1, A D}$ és $f_{2, A D}$ faktorai

What the above formulae express is, in essence, that the thickness of the dispersing agent is directly proportional to the size of the particles in the dispersed phase, and the proportionality ratio depends on the volumetric ratio of the dispersing agent and the dispersed phase. One of the tasks of a concrete engineer in connection with this topic is to determine - for concrete constituents - the volumetric ratio that achieves the optimum dispersing agent thickness in relation with the distribution of the dimensions of solid particles, in order to reach the targeted consistency.

\section{Results and evaluation of plant observations}

\subsection{General data}

Consistency was measured by the flow table test acc. to EN 12350-5 within $15 \pm 5$ minutes of the start of mixing the concrete. The compositional properties of the mixes examined were hardly altered from those described in Table 5 of [6], although the database had been updated with the data from new mixes. The current data is summarised in Table 11. More detailed data on the concrete composition content indicators of the mixes prepared with admixtures are summarised in Table 12. It can be realised from the data in Table 12 that the mixing plant produced an overwhelming majority of concrete mixes of F2 and F3 consistency according to EN 206-1, according to its customer orders.

A general presentation of the data would be incomplete without showing the range limits of the variations in particle distributions of the mixes of sand and gravel fractions. The distribution curves of all aggregate mixes have been condensed into the single diagram in Fig. 29, which shows the distribution according to the surface area pass calculated for the unit of volume rather than the volume or mass percentage pass. It can be seen that there are considerable differences in the volumetric specific surface areas over $0.5 \mathrm{~mm}$ particle size, changing between $4000-6000 \mathrm{~m}^{2} / \mathrm{m}^{3}$. The influence of the volumetric specific surface area is, therefore, expected to be a major factor when considering the consistency of the mixes.

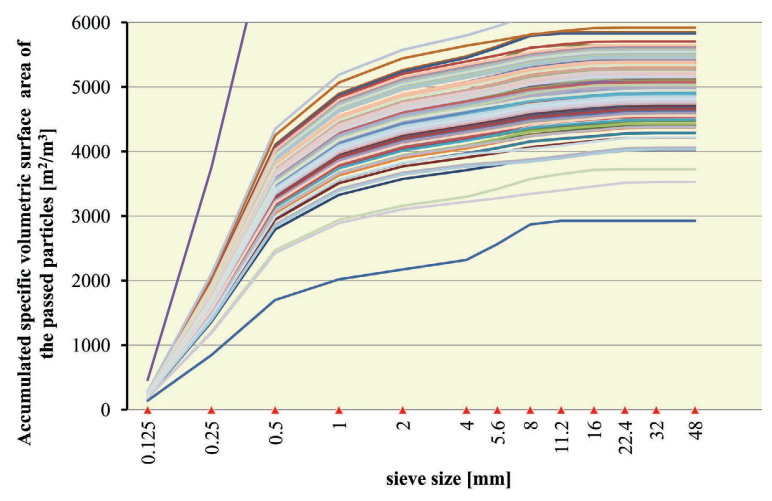

Fig. 29. Surface area distribution of aggregate mixes used between 2008-2011 (the single curve that leaves the chart is for sand with a volumetric specific surface area of $\sim 12000 \mathrm{~m}^{2} / \mathrm{m}^{3}$ )

29. ábra A 2008-2011 között felhasznált adalékanyag-keverékek felületeloszlásai (az ábrából kifutó egyetlen görbe egy $\sim 12000 \mathrm{~m}^{2} / \mathrm{m}^{3}$ térfogati fajlagos felületü homokhoz tartozik) 


\subsection{Relationship between consistency and concrete composition content indicators}

In processing the results of the observations, correlations were initially sought in the data of mixes made without admixtures, and the basic equations derived from the analysis were later used for compositions containing admixtures to calculate factors that expressed the effects of the admixtures. The equation that was found to match most closely the observed measured results is shown in Eq. (39).

$$
\text { Flow }[\mathrm{mm}]=\left(1+\mathrm{f}_{1, \mathrm{AD}} \cdot \lambda_{\mathrm{AD}}\right) \cdot \mathrm{f}_{2, \mathrm{AD}} \cdot \mathrm{A} \cdot \frac{\left(\frac{x}{f_{z}}\right)^{\mathrm{n}_{\mathrm{x}}}}{\left(1+\frac{a \cdot f_{\mathrm{a}}}{z \cdot f_{\mathrm{z}}}\right)^{\mathrm{n}_{\mathrm{f}}} \cdot\left(1+\frac{a}{z}\right)^{\mathrm{n}_{\mathrm{a}}}}
$$

Flow is the estimated flow value $[\mathrm{mm}]$ of the concrete mix by flow table,

$\lambda_{\mathrm{AD}}$ is the dose of admixture in the volumetric ratio of paste powder (concrete composition content indicator),

$\mathrm{f}_{1, \mathrm{AD}}$ is the dose factor of the admixture (for specific values of the observed admixtures, see Table 12),

$\mathrm{f}_{2, \mathrm{AD}}$ is the factor typical of the material of the admixture (for specific values of the observed admixtures, see Table 12),

$\mathrm{A}$ is the experimental constant, in this case $\mathrm{A}=39386.8$, $\mathrm{n}_{\mathrm{x}}, \mathrm{n}_{\mathrm{f}}$ and $\mathrm{n}_{\mathrm{a}}$ are exponents, with observed values as follows: $\mathrm{n}_{\mathrm{x}}=0.288, \mathrm{n}_{\mathrm{f}}=1.208$ and $\mathrm{n}_{\mathrm{a}}=0.319$,

$f_{\mathrm{z}}$ is the volumetric specific surface area of the paste powder $\left[\mathrm{m}^{2} / \mathrm{m}^{3}\right]$,

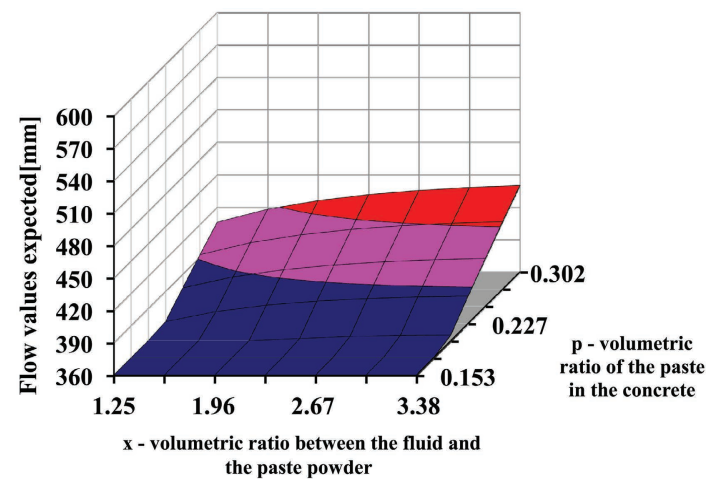

Fig. 30. Expected flow values for mixes made without admixture $\left(\lambda_{A D}=0\right)$ in the observed $p$ - $x$ range

30. ábra Adalékszer nélküli $\left(\lambda_{A D}=0\right)$ keverékek terüléseinek várható értékei a megfigyelt p-x tartományban

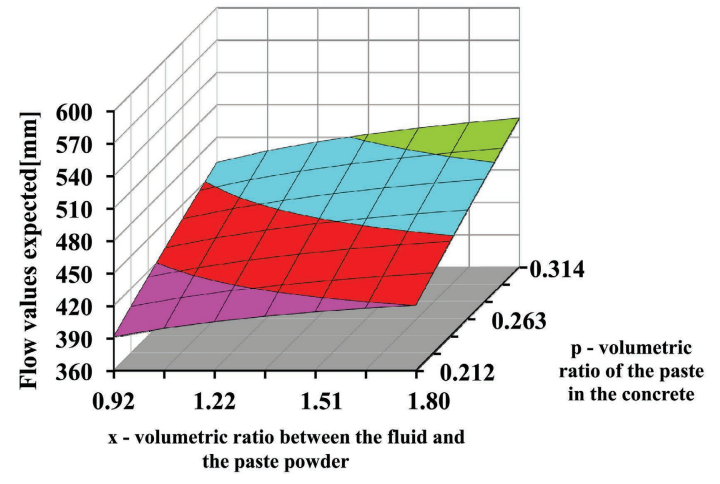

Fig. 31. Expected flow values for medium $\left(\lambda_{A D}=0.016\right)$ doses of MRWR admixture in the observed $p$ - $x$ range

31. ábra Erös hatású adalékszer $(M R W R)$ közepes $\left(\lambda_{A D}=0,016\right)$ adagolása mellett elérhetö terülések várható értékei a megfigyelt p-x tartományban $f_{\mathrm{a}}$ is the volumetric specific surface area of the aggregate $\left[\mathrm{m}^{2} / \mathrm{m}^{3}\right]$, $z$ is the volumetric ratio of paste powder in the concrete, $a$ is the volumetric ratio of aggregate in the concrete, and the other notations are the same as for Eqs. (37) and (38).

The correlation is quite weak $\left(\mathrm{R}^{2} \approx 0.29\right)$, which is not surprising in the case of consistency, but the significance of the equation's multiplication factor was proved with a probability of $\mathrm{p}=0.06$. The confidence interval for the flow values obtained from estimates was $\pm 88 \mathrm{~mm}$ at a probability level of $95 \%$ and $\pm 36 \mathrm{~mm}$ at a probability level of $67 \%$. An interesting feature of the relationship is that when $a=0$ (that is, for pure paste) it assumes the maximum value, which complies with the principles defined by Alexanderson. What is new is that it also takes into account the influence of the dose of admixture $\left(\lambda_{\mathrm{AD}}\right)$, as well as its effectiveness $\left(\mathrm{f}_{1, \mathrm{AD}}\right)$ and the influence of its type $\left(f_{2, A D}\right)$. For the latter, a value that very closely approaches unity was obtained during the plant observations (see Table 12). Where mixes without admixture are concerned, the equation gives the estimated flow values for mixes with only water added, since $\mathrm{f}_{1, \mathrm{AD}}=\mathrm{f}_{2, \mathrm{AD}}=1$ if $\lambda_{\mathrm{AD}}=0$.

The flow values estimated from Eq. (39) must be regarded as expected values, which can assume any value within the confidence interval given above, but the calculated values are the most probable (expected) values. A few illustrations from processing the results are shown in Figs. 30 to 33. It can be realised from Fig. 33 that for a given w/c range and paste

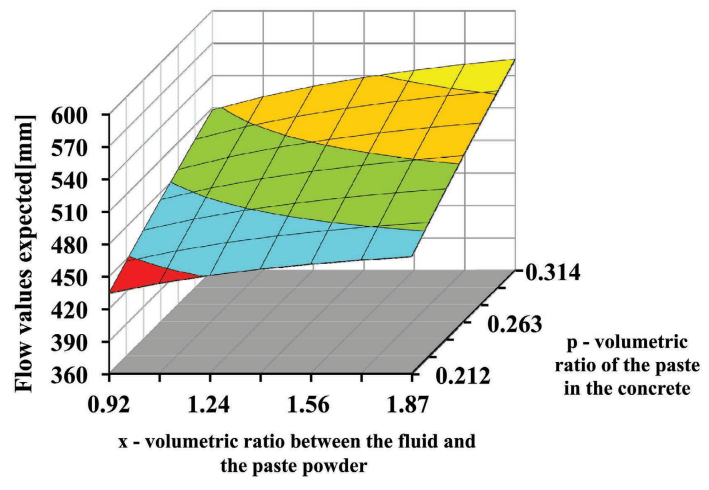

Fig. 32. Expected flow values for high $\left(\lambda_{A D}=0.030\right)$ doses of HRWR admixture in the observed $p-x$ range

32. ábra Nagyon erös hatású adalékszer $(H R W R)$ magas $\left(\lambda_{A D}=0,030\right)$ adagolása mellett elérhetö terülések várható értékei a megfigyelt p-x tartományban

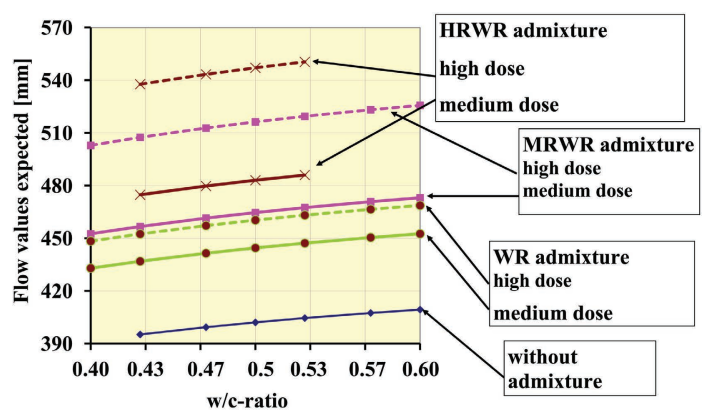

Fig. 33. Consistencies obtained with different admixtures, and without admixtures, depending on dosage, in the case of concrete mixes with a paste content of $280 \mathrm{l} / \mathrm{m}^{3}$, air content of $20 \mathrm{l} / \mathrm{m}^{3}$, and no additions

33. ábra A különbözö adalékszerekkel, és azok nélkül elérhetö konzisztenciák az adagolás függvényében $280 \mathrm{liter} / \mathrm{m}^{3}$ péptartalmú, 20 liter $/ \mathrm{m}^{3}$ levegötartalmú kiegészitöanyagot nem tartalmazó betonkeverékek esetén 
content, a high dosage of the medium range admixture may perform almost identically to a medium dosage of high range admixture. Increasing the dosage of admixture within a certain limit is a more significant influence than increasing the $\mathrm{w} / \mathrm{c}$ ratio.

\section{Material balance equations of concrete mixes}

According to the definition given in the EN 206-1 European Standard concrete is a "material formed by mixing cement, coarse and fine aggregate and water, with or without the incorporation of admixtures, additions or fibres, which develops its properties by hydration" [9]. In addition to this definition - taking account of recent developments in the field of concrete engineering - the simple basic model for concrete mixes also regards concrete in its fresh state as a macroscopically heterogeneous composite system consisting of solid phase (aggregates), liquid phase (paste) and gaseous phase (air), in which the paste is itself a heterogeneous system, likewise consisting of three separate phases, which are:

- $\quad$ solid phase paste powder (cement, as a hydraulic bonding agent, perhaps together with (a mixture of) fine-grain additions, which are inert or have pozzolanic reactivity, latent hydraulic reactivity, etc.),

- liquid phase water (which may also contain one or more dissolved admixtures) and

- gaseous phase air (which may be intentionally added air bubbles by air entraining admixture, or just randomly remaining voids due to incomplete compaction).

A $\mathrm{V}_{\text {concrete }}\left[\mathrm{m}^{3}\right]$ volume of (fresh) concrete mix generally consists of five main concrete constituent components, while certain concrete constituents may themselves be made up of mixtures of sub-constituents (in known proportions):

$\mathrm{K}_{\text {virt }}{ }^{*}[\mathrm{~kg}]$ : total additions; $\mathrm{K}_{\text {virt }}=\Sigma\left(\alpha_{M, \text { Kvirt }, i} \mathrm{~K}_{\text {virt,i }}\right)$, where $\alpha_{M, \text { Kvirt }, i}$ is the mass ratio of the $i^{\text {th }} \mathrm{K}_{\text {virt,i }}[\mathrm{kg}]$ addition component, and where $0 \leq \alpha_{M, \text { Kvirt }, i} \leq 1$ and $\Sigma \alpha_{M, \text { Kvirt }, i}=1$,

c [kg]: quantity of cement added,

$\mathrm{AG}_{\mathrm{virt}}{ }^{*}[\mathrm{~kg}]$ : total (wet) aggregates; $\mathrm{AG}_{\text {virt }}=\Sigma\left(\alpha_{M, A G \text { virt } \mathrm{j}} \mathrm{AG}_{\mathrm{virt}, \mathrm{j}}\right)$, where $\alpha_{M, A \text { Gvirt, } j}$ is the mass ratio of the $\left.j^{\text {th }} A G_{\text {virt, } j}^{M, A g}\right]$ aggregate component, and where $0 \leq \alpha_{M, A G v i r t, j} \leq 1$ and $\sum \alpha_{M, A \text { Girt }, j}=1$,

$\mathrm{W}_{\text {virt }}{ }^{*}[\mathrm{~kg}]$ : quantity of water added when blending the concrete mix,

$\mathrm{AD}[\mathrm{kg}]$ : total admixtures; $\mathrm{AD}=\Sigma\left(\alpha_{M, A D, k} \mathrm{AD}_{\mathrm{k}}\right)$, where

$\alpha_{M, A D, k}$ is the mass ratio of the $k^{\text {th }} \mathrm{AD}_{\mathrm{k}}[\mathrm{kg}]$ admixture

component, and where $0 \leq \alpha_{M, A D, k} \leq 1$ and $\alpha_{M, A D, k}=1$.
"Note: the "virt" (virtual) symbol used above expresses that parts belonging to the different phases of the concrete are (or may be) present in the concrete constituent components. For example, the part of the addition material which is larger than $0.063 \mathrm{~mm}$ is included in the solid phase of the aggregate, while the part of the aggregate which is smaller than $0.063 \mathrm{~mm}$ is included in the fluid paste as paste powder. The water which adheres to the surface of the aggregate, and which in many cases is not negligible, is also included in the paste - as a liquid - so in addition to the $\mathrm{W}_{\text {virt }}$ added water, this must also be taken into consideration in the liquid phase of the concrete.

The structural composition of concrete mixes described by the mass data above may also be basically described using five dimensionless ratios:

$p$ : the volumetric ratio of paste in the concrete $(0<p \leq 1)$, $x$ : the volumetric ratio of the (free) liquid and the paste

powder in the paste $(x>0$, but generally in practice: $\sim 0.6 \leq$ $x \leq \sim 3.6$ ),

$l$ : the volumetric ratio of air (void) in the concrete $(0 \leq k<1$, generally in practice: $\sim 0.010 \leq l \leq \sim 0.060 \ldots 0.120, \ldots)$,

$\chi_{c}$ : the volumetric ratio of cement in the paste powder $\left(0<\chi_{c}\right.$ $\leq 1$, if the paste is pure cement $\chi_{c}=1$ ),

$\lambda_{A D}$ : the combined volumetric ratio of the admixture compared with the paste powder, (where the $\lambda_{A D, k}$ ratios of individual - different effect - admixture components are $\lambda_{A D, k} \geq 0$, where the concrete mix contains no admixture $\lambda_{A D, k}=0$; in general, however, $\lambda_{A D, k}=\sim 0.005 \ldots 0.050$, and is therefore a small value).

The correlations between the concrete composition content indicators and the amounts of the given concrete constituents with known physical properties are defined by the system of linear equations in the matrix equation shown in Eq. (40), where:

$\varphi_{\mathrm{K}, \mathrm{i}}$ : the part of the $i^{\text {th }}$ addition component which is smaller than $0.063 \mathrm{~mm}$, as mass ratio,

$\rho_{\mathrm{K}, \mathrm{i}}\left[\mathrm{kg} / \mathrm{m}^{3}\right]$ : the dried particle density of the $i^{\text {th }}$ addition component,

$\rho_{c}\left[\mathrm{~kg} / \mathrm{m}^{3}\right]$ : the particle density of the cement (in dry state), $\varphi_{\mathrm{AG}, \mathrm{j}}$ : the part of the $j^{\text {th }}$ aggregate component which is smaller than $0.063 \mathrm{~mm}$, as mass ratio,

$\mathrm{W}_{\mathrm{AG}, \mathrm{j}}$ : the moisture content of the $j^{\text {th }}$ aggregate component as mass ratio,

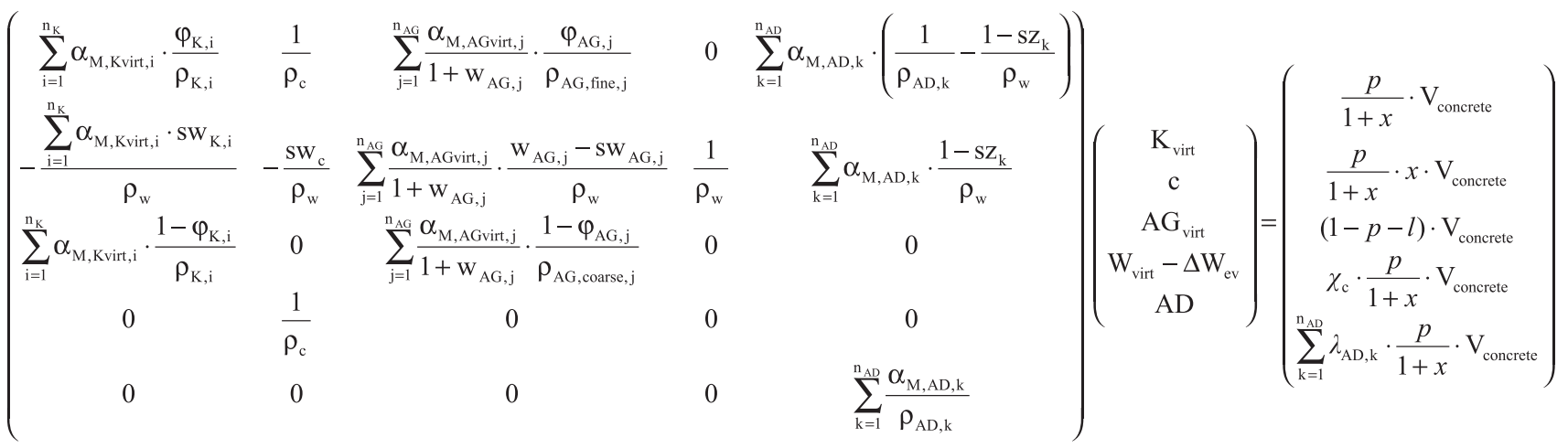


$\rho_{\mathrm{AG}, \mathrm{j}, \text { fine }}\left[\mathrm{kg} / \mathrm{m}^{3}\right]:$ the dried particle density of the part of the $j^{\text {th }}$ aggregate component which is smaller than $0.063 \mathrm{~mm}$,

$\rho_{\mathrm{AD}, \mathrm{k}}\left[\mathrm{kg} / \mathrm{m}^{3}\right]$ : the density of the $k^{\text {th }}$ admixture component,

$\mathrm{sz}_{\mathrm{k}}$ : the dry content of the $k^{\text {th }}$ addition component, as mass ratio,

$\rho_{\mathrm{w}}\left[\mathrm{kg} / \mathrm{m}^{3}\right]$ : water density,

$\mathrm{sW}_{\mathrm{K}, \mathrm{i}}$ : (short-term) water absorption of the $i^{\text {th }}$ addition component, as mass ratio,

$\mathrm{SW}_{\mathrm{c}}$ : (short-term) water absorption of cement, as mass ratio, $\mathrm{sW}_{\mathrm{AG}, \mathrm{j}^{\circ}}$ ( (short-term) water absorption of the $j^{\text {th }}$ aggregate component, as mass ratio,

$\rho_{\mathrm{AG}, \mathrm{j}, \text { coarse }}\left[\mathrm{kg} / \mathrm{m}^{3}\right]$ : the dried particle density of the part of the $j^{\text {th }}$ aggregate component which is larger than $0.063 \mathrm{~mm}$,

$\Delta \mathrm{W}_{\mathrm{ev}}[\mathrm{kg}]$ the water that evaporates from the concrete mix with a volume $\mathrm{V}_{\text {concrete }}\left[\mathrm{m}^{3}\right]$ until it is worked in,

$\lambda_{\mathrm{AD}, \mathrm{k}}$ : the ratio of the volume of the $k^{\text {th }}$ admixture component compared with the volume of the paste powder,

the other notations are the same as previously explained.

The system of linear equations presented in the matrix equation of Eq. (40) is fundamental in the mix design, determining the composition of concrete mixes. The system of equations expresses the fact that (fresh) concrete mixes are made up of a linear combination of the constituent phases of components. The matrix factor that may be regarded as known in the product on the left hand side of the equation (materials property matrix) contains the physical properties and compositional proportions (e.g.: fraction ratios) of the concrete constituent materials, while the vector factor of the product (mix composition vector) expresses the masses of the concrete constituents which are to be added - and which may be regarded as unknown during mix design. The so-called structural vector on the right hand side of the equation contains the volumes of paste powder, paste fluid and aggregates in a designed volume of concrete, as well as the volume of cement and the volume of the admixtures, respectively. The structural vector directly depends on the targeted concrete composition content indicators, which are either already known during mix design, or are determined on the basis of prior knowledge of particular correlations.

The mix composition vector and the structural vector mutually define each other in a clear way, so the design of the composition of concrete mixes is possible by solving the matrix equation of Eq. (40). During concrete mix design for a volume $\mathrm{V}_{\text {concrete }}$, the first step is to determine the concrete composition content indicators, from which the structural vector on the right hand side of the matrix equation of Eq. (40) can be obtained. The matrix equation of Eq. (40) can be set up by the materials property matrix that contains the material properties and particular component proportions. The solution of the system of linear equations provides the mix composition vector, which produces, as a direct result, the quantities of the concrete constituents that are to be added to the targeted concrete mix with a volume $\mathrm{V}_{\text {coce }}$

It should be noted that Eq. (40) (and therefore the concrete mix) may only be clearly defined if all the concrete composition content indicators are known. It also follows that fully comprehensive consequences can in theory only be drawn from observations related to concrete mixes, if the influence of each concrete composition content indicator has been taken into account and evaluated.

\section{Using the simple basic model to design the composition of concrete mixes to meet given criteria}

Several concrete mix design methods are available which meet pre-defined criteria. The common principle behind the different methods is to search for compositions which meet the criteria by counting back from the design criteria (e.g. compressive strength and consistency), which assumes that accepted correlations are available, as is the case with the Palotás-Bolomey [10,11] and Ujhelyi [2] methods used widespread in Hungary for concretes without admixtures.

New correlations are necessary for concrete mix design with admixtures. The simple basic model for concrete mixes provides this opportunity: the use of material balance equations is included, and greater flexibility in applying correlations with a restricted range of validity in connection with the influences of factors is offered; that are developed through experiments.

In the followings, a specific example illustrates the essence of the method.

\section{Example for concrete mix design}

The present example details the steps of concrete mix design by the simple basic model for a concrete mix with designation C30/37-XC3-16-F4-MSZ 4798-1:2004.

\subsection{Identifying and determining requirements}

Compressive strength: The concrete in the example needs to have a characteristic compressive strength of $\mathrm{f}_{\text {ck,cube }}$ according to MSZ EN 206-1 standard that lies between the minimum values for compressive strength prescribed for compressive strength classes C30/37 and C35/45, i.e. $37 \mathrm{~N} / \mathrm{mm}^{2} \leq \mathrm{f}_{\mathrm{ck} \text {,cube }}<45 \mathrm{~N} / \mathrm{mm}^{2}$. It is possible to ensure the characteristic compressive strength in continuous production if the mean compressive strength of the concrete meets the condition of $\mathrm{f}_{\mathrm{cm}} \geq \mathrm{f}_{\mathrm{ck} \text {,cube }}+1.48 \times \sigma$, where $\sigma$ $\geq 3 \mathrm{~N} / \mathrm{mm}^{2}$ is acceptable in the example. The estimate for the standard deviation of a population is recorded at $10 \%$ of the expected mean compressive strength of the concrete in the example, and the range of values for characteristic compressive strength is narrowed by $10 \%$ at both the upper and lower limits for safety reasons (which results $37.8 \mathrm{~N} / \mathrm{mm}^{2} \leq \mathrm{f}_{\text {ck,cube }}<44.2 \mathrm{~N} /$ $\mathrm{mm}^{2}$ ). The achieved result safely fulfil the given conditions for compressive strength if the mean compressive strength lies in the range $44.4 \mathrm{~N} / \mathrm{mm}^{2} \leq \mathrm{f}_{\mathrm{cm}}<51.9 \mathrm{~N} / \mathrm{mm}^{2}$.

Consistency: The flow value $[\mathrm{mm}]$ prescribed for consistency class F4 according to MSZ EN 206-1 standard lies in the range $490 \mathrm{~mm} \leq$ Flow $\leq 550 \mathrm{~mm}$. In view of the uncertainties in estimating consistency, the range midpoint of Flow $=520 \mathrm{~mm}$ has been taken as the criterion.

Composition criteria: The recommendations according to MSZ EN 206-1 standard for exposure class XC3 are $w / c \leq 0.55$ and $c \geq 280 \mathrm{~kg} / \mathrm{m}^{3}$. Further requirements in Hungary are the minimum body density of fresh concrete of $2380 \mathrm{~kg} / \mathrm{m}^{3}$ and the minimum body density of hardened concrete of $2310 \mathrm{~kg} / \mathrm{m}^{3}$. 


\begin{tabular}{|c|c|c|c|c|c|c|c|c|c|c|c|c|c|}
\hline \multicolumn{2}{|c|}{ Components of concrete } & \multicolumn{2}{|c|}{$\begin{array}{c}\text { Mass ratios } \\
\text { in constituents }\end{array}$} & \multicolumn{2}{|c|}{$\begin{array}{l}\text { volumetric } \\
\text { specific } \\
\text { surface }\end{array}$} & \multicolumn{2}{|c|}{$\begin{array}{l}\text { fine-content } \\
(<0.063 \mathrm{~mm})\end{array}$} & \multicolumn{2}{|c|}{ Dry densities } & \multicolumn{2}{|c|}{$\begin{array}{l}\text { Moisture } \\
\text { content }\end{array}$} & \multicolumn{2}{|c|}{$\begin{array}{c}\text { Absorption of } \\
\text { water }\end{array}$} \\
\hline $\mathrm{W}_{\text {virt }}$ & water & & & & & & & $\rho_{\mathrm{w}}=$ & 999 & & & & \\
\hline$A D$ & MRWR admixture & $a_{M, A D, 1}=$ & 1,000 & & & & & $\rho_{\mathrm{AD}, 1}=$ & 1070 & $1-\mathrm{sz}_{1}=$ & $70,0 \%$ & & \\
\hline c & CEM II/A-M (V-LL) 42,5 N & & & \multicolumn{2}{|c|}{$f_{c}=1208000$} & & & $\rho_{\mathrm{c}}=$ & 3000 & & & $\mathrm{sw}_{\mathrm{c}}=$ & $1,51 \%$ \\
\hline $\mathrm{K}_{\text {virt }}$ & inert basalt powder & $a_{M, K v i r t, 1}=$ & 1,000 & \multicolumn{2}{|c|}{$f_{K}=1456000$} & $\Phi_{\mathrm{K}, 1}=$ & $88,0 \%$ & $\rho_{\mathrm{K}, 1}=$ & 2763 & & & $\mathrm{sw}_{\mathrm{k}, 1}=$ & $0,50 \%$ \\
\hline \multirow{3}{*}{$A G_{\text {virt }}$} & $0 / 4_{\text {virt }}$ & $a_{M, A G v i r t, 1}=$ & 0,451 & 9859 & & $\Phi_{\mathrm{AG}, 1}=$ & $0,4 \%$ & $\begin{array}{r}\rho_{\mathrm{AG}, \text { fine }, 1}= \\
\rho_{\mathrm{AG}, \text { coarse }, 1}=\end{array}$ & \multirow{3}{*}{2640} & $\mathrm{w}_{\mathrm{AG}, 1}=$ & $3,49 \%$ & $\mathrm{sW}_{\mathrm{AG}, 1}=$ & $0,20 \%$ \\
\hline & $4 / 8_{\text {virt }}$ & $a_{M, A G v i r t, 2}=$ & 0,280 & 1365 & $\begin{array}{l}f a= \\
5034\end{array}$ & $\Phi_{\mathrm{AG}, 2}=$ & $0,3 \%$ & $\begin{array}{r}\rho_{\mathrm{AG}, \text { fine }, 2}= \\
\rho_{\mathrm{AG}, \text { coarse }, 2}=\end{array}$ & & $\mathrm{W}_{\mathrm{AG}, 2}=$ & $1,71 \%$ & $\mathrm{sw}_{\mathrm{AG}, 2}=$ & $0,95 \%$ \\
\hline & $8 / 16_{\text {virt }}$ & $a_{M, A G v i r t, 3}=$ & 0,269 & 926 & & $\Phi A_{\mathrm{G}, 3}=$ & $0,2 \%$ & $\begin{array}{r}\rho_{\mathrm{AG}, \text { fine }, 3}= \\
\rho_{\mathrm{AG}, \text { coarse }, 3}=\end{array}$ & & $\mathrm{W}_{\mathrm{AG}, 3}=$ & $1,21 \%$ & $\mathrm{sW}_{\mathrm{AG}, 3}=$ & $0,95 \%$ \\
\hline
\end{tabular}

Table 13. Data of the concrete constituents that are available for concrete with designation C30/37-XC3-16-F4-MSZ 4798-1:2004, which is to be designed in the example (note: $s z_{1}$ refers to dry content of the MRWR admixture)

13. táblázat A példa szerint tervezendö C30/37-XC3-16-F4-MSZ 4798-1:2004 jelü betonhoz rendelkezésre álló betonalkotók adatai

\begin{tabular}{|c|c|c|c|c|c|c|c|c|c|}
\hline \multirow{2}{*}{\multicolumn{2}{|c|}{$\begin{array}{l}\text { Type of cement taken into account } \\
\text { CEM II A-M (V-LL) 42,5 N }\end{array}$}} & \multicolumn{5}{|c|}{ Content (stuctural) indicators } & \multicolumn{3}{|c|}{ Other technical data } \\
\hline & & $\mathbf{p}$ & $\mathbf{x}$ & $X_{c}$ & $\lambda_{\mathrm{AD}}$ & I & $\begin{array}{l}\text { tradi- } \\
\text { tional } \\
\text { w/c }\end{array}$ & $a^{*}$ & $\begin{array}{l}D_{\max } \\
\mathbf{m m}\end{array}$ \\
\hline \multirow{4}{*}{$\begin{array}{l}\text { Augusztin Betongyártó Ltd. } \\
2008-2010 \text {. } \\
46 \text { observations }\end{array}$} & $\min$. & 0.204 & 1.294 & 0.750 & 0.010 & 0,000 & 0.484 & 0.686 & 8 \\
\hline & $\max$. & 0.302 & 2.327 & 0.974 & 0.026 & 0.041 & 1.048 & 0.756 & 32 \\
\hline & AVG. & 0.261 & 1.753 & 0.822 & 0.019 & 0.012 & 0.729 & 0.727 & 24,5 \\
\hline & STD. & 0.016 & 0.243 & 0.055 & 0.006 & 0.007 & 0.138 & 0.014 & 8 \\
\hline
\end{tabular}

Table 14. Concrete composition content indicators and other data of CEM II/A-M (V-LL) $42.5 \mathrm{~N}$ mixes evaluated during industrial observations ( $a^{*}$ : volumetric ratio of the aggregate in the concrete mix)

14. táblázat Az üzemi megfigyelések során értékelésbe vont CEM II/A-M (V-LL) 42,5 N keverékek betonösszetételi állapotjelzői és néhány más adata ( $a^{*}$ : a betonkeverékben lévö adalékanyag térfogataránya)

\begin{tabular}{|c|c|c|c|c|c|c|c|c|c|c|c|c|}
\hline \multirow[b]{2}{*}{ Admixture code } & \multirow[b]{2}{*}{$\begin{array}{c}\text { Observations } \\
\text { (no.) }\end{array}$} & \multicolumn{2}{|c|}{$\begin{array}{c}p \text { - paste volu- } \\
\text { metric ratio }\end{array}$} & \multicolumn{2}{|c|}{$\begin{array}{l}x \text { - liquid-pow- } \\
\text { der volumetric } \\
\text { ratio factor } \\
\end{array}$} & \multicolumn{3}{|c|}{$\begin{array}{c}\lambda \text { - dose of admixture in } \\
\text { the paste powder volumet- } \\
\text { ric ratio }\end{array}$} & \multicolumn{2}{|c|}{$\begin{array}{l}\text { Measured Flow } \\
{[\mathrm{mm}]}\end{array}$} & \multicolumn{2}{|c|}{$\begin{array}{c}\text { Factors in } \\
\text { the estimation } \\
\text { formula } \\
\end{array}$} \\
\hline & & $p_{\min }$ & $p_{\max }$ & $x_{\min }$ & $x_{\max }$ & $\lambda_{\min }$ & $\lambda_{\text {AvG }}$ & $\lambda_{\max }$ & Flow $_{\text {min }}$ & Flow $_{\text {max }}$ & $f_{1, A D}$ & $f_{2, A D}$ \\
\hline MRWR & 10 & 0.212 & 0.314 & 0.924 & 1.872 & 0.008 & 0.016 & 0.030 & 340 & 590 & 8.868 & 1.012 \\
\hline
\end{tabular}

Table 15. Data on the concrete composition content indicators and consistency measurements of mixes made by mid-range water-reducing MRWR admixture, and the $f_{l, A D}$ and $f_{2, A D}$ factors of the consistency estimation formula of Eq. (42)

15. táblázat Az erös hatású adalékszerrel (MRWR) készitett keverékek betonösszetételi állapotjelzőinek és konzisztencia mértékszámainak adatai, valamint a konzisztenciabecslö (42) képlet $f_{1, A D}$ és $f_{2, A D}$ faktorai

\begin{tabular}{|c|c|c|c|c|c|c|c|c|c|c|c|c|c|c|c|c|c|c|c|c|c|c|}
\hline \multirow[b]{2}{*}{ No } & \multicolumn{7}{|c|}{ Target parameters and content inicators } & \multicolumn{5}{|c|}{$\begin{array}{c}\text { Composition (for dry aggregates) } \\
\mathrm{kg} / \mathrm{m}^{3}\end{array}$} & \multicolumn{7}{|c|}{ Design composition (for wet aggregates) kg/m $\mathrm{m}^{3}$} & \multicolumn{3}{|c|}{ Checking } \\
\hline & $\begin{array}{l}\mathbf{f}_{\mathrm{cm} 28, \mathrm{exp}} \\
{\left[\mathrm{N} / \mathrm{mm}^{2}\right]}\end{array}$ & $\begin{array}{l}\text { Flow }_{\text {exp }} \\
{[\mathrm{mm}]}\end{array}$ & p & $X_{\mathrm{c}}$ & I & $x$ & $\begin{array}{c}\lambda_{\mathrm{AD}} \\
(\mathrm{MRWR})\end{array}$ & $\mathrm{K}$ & $\begin{array}{c}\text { CEM } \\
\text { II/ A-M } \\
42.5\end{array}$ & $A G$ & W & $\begin{array}{c}\mathrm{AD}_{1} \\
\text { (MRWR) }\end{array}$ & $\begin{array}{l}\text { stone } \\
\text { pow- } \\
\text { der }\end{array}$ & $\begin{array}{c}\text { CEM } \\
\text { II/ A-M } \\
42.5\end{array}$ & $\begin{array}{l}0 / 4 \\
\text { sand }\end{array}$ & $\begin{array}{c}4 / 8 \\
\text { gravel }\end{array}$ & $\begin{array}{l}8 / 16 \\
\text { gravel }\end{array}$ & $W_{\text {virt }}$ & $\begin{array}{c}\mathrm{AD}_{1} \\
(\mathrm{MRWR})\end{array}$ & $w / C$ & $\begin{array}{c}\rho_{\text {fresh }} \\
\mathrm{kg} / \mathrm{m}^{3}\end{array}$ & $\begin{array}{l}\text { expo- } \\
\text { sure } \\
\text { class }\end{array}$ \\
\hline 1 & 44,4 & 520 & 0,280 & 0,850 & 0,020 & 1,333 & 0,034 & 46 & 306 & 1849 & 173 & 4,32 & 46 & 306 & 853 & 530 & 509 & 129 & 4,32 & 0,54 & 2379 & $\mathrm{XC3}$ \\
\hline 2 & 44,4 & 520 & 0,280 & 0,972 & 0,020 & 1,560 & 0,030 & -0 & 319 & 1854 & 184 & 3,54 & -0 & 319 & 856 & 532 & 510 & 140 & 3,54 & 0,55 & 2361 & $\mathrm{XC2}$ \\
\hline 3 & 44,4 & 520 & 0,300 & 0,850 & 0,020 & 1,317 & 0,030 & 51 & 330 & 1795 & 184 & 4,11 & 51 & 330 & 829 & 515 & 494 & 141 & 4,11 & 0,53 & 2365 & $\mathrm{XC2}$ \\
\hline 4 & 44,4 & 520 & 0,300 & 0,975 & 0,020 & 1,559 & 0,026 & -0 & 343 & 1801 & 197 & 3,27 & -0 & 343 & 831 & 517 & 496 & 154 & 3,27 & 0,55 & 2344 & $x_{0}$ \\
\hline 5 & 51,9 & 520 & 0,280 & 0,850 & 0,020 & 1,183 & 0,036 & 50 & 327 & 1848 & 165 & 4,91 & 50 & 327 & 853 & 530 & 509 & 121 & 4,91 & 0,48 & 2395 & XC4 \\
\hline 6 & 51,9 & 520 & 0,280 & 0,973 & 0,020 & 1,408 & 0,032 & -0 & 339 & 1854 & 177 & 3,96 & -0 & 339 & 856 & 532 & 510 & 133 & 3,96 & 0,50 & 2375 & $\mathrm{XC3}$ \\
\hline 7 & 51,9 & 520 & 0,300 & 0,850 & 0,020 & 1,168 & 0,032 & 55 & 353 & 1795 & 175 & 4,72 & 55 & 353 & 828 & 515 & 494 & 133 & 4,72 & 0,47 & 2382 & XC3 \\
\hline 8 & 51,9 & 520 & 0,300 & 0,976 & 0,020 & 1,396 & 0,028 & -0 & 366 & 1801 & 189 & 3,72 & -0 & 366 & 831 & 517 & 496 & 146 & 3,72 & 0,49 & 2360 & XC2 \\
\hline
\end{tabular}

Table 16. The composition calculations performed on the basis of the example criteria, where $f_{\text {cm,28,exp }}$ and Flow exp $_{\text {are }}$ the assumed design criteria (target parameters),

$p, \chi_{c}$ and l are freely selected, and $x, \lambda_{A D}$ are calculated content indicators dependent on the preceding. The Table contains the recipes derived from solving the matrix equation of Eq. (40), mixing instructions (for wet aggregate components) and a control column for the exposure requirements

16. táblázat A példa szerinti kritériumok alapján végzett összetétel-számitások, ahol az $f_{c m, 28, e x p}$ és Flow ${ }_{\text {exp }}$ felvett tervezési kritériumok (célparaméterek), p, $\chi_{c}$ és $l$ szabadon választott, az $x, \lambda_{A D}$ pedig ezektöl függő számított állapotjelzök. A táblázat tartalmazza a (40) egyenletrendszer megoldásából kapott receptúrákat, keverési utasitásokat (nedves adalékanyag-komponensekre) és egy ellenörzö blokkot a kitéti követelményekre 
6.2 Identifying the concrete constituent materials and determining their properties

The example does not take the quantity of evaporating water into consideration, so $\Delta \mathrm{W}_{\mathrm{ev}}=0$, and the other available materials and their properties are listed and presented in Table 13 and in Fig. 34.

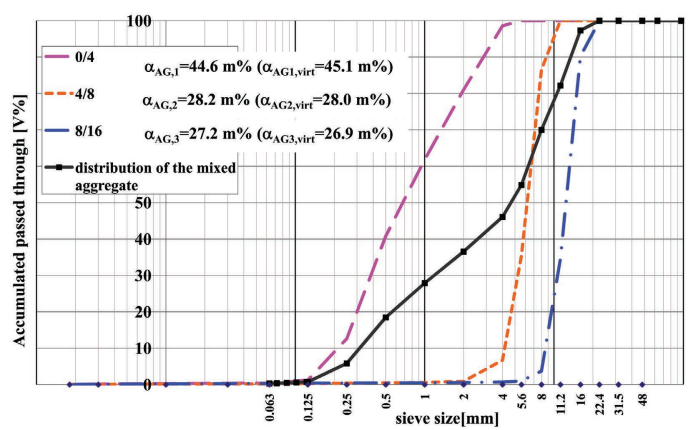

Fig. 34. Data on the particle distribution of aggregates that are available for concrete with designation C30/37-XC3-16-F4-MSZ 4798-1:2004, which is to be designed in our example.

34. ábra A példa szerint tervezendő C30/37-XC3-16-F4-MSZ 4798-1:2004 jelü betonhoz rendelkezésre álló adalékanyagok szemeloszlási adatai

\subsection{Identifying the correlations related to the design criteria as target parameters}

Instead of searching for new, universally valid correlations, the simple basic model for concrete mixes preferably relies on local correlations, obtained through experience from controlled experimental data, whose validity is restricted to the materials used in the given experiment and their range of interpretation. Such experimental correlations may be obtained at any concrete mixing plant where industrial production is controlled under supervision by trained professional concrete technicians.

The correlations obtained through experience are used here that relate to compressive strength and to consistency. Validity extends to the concrete constituents identified in paragraph 6.2. 46 observations are available for the compressive strength of mixes made from CEM II/A-M (V-LL) $42.5 \mathrm{~N}$ cement, and 10 observations are available for the consistence of mixes with MRWR admixture (see Tables 14 and 15).

For the experiential correlations used for compressive strength Eq. (33) applies, but replacing $f_{c, 28}$ with $f_{\mathrm{cm}, 28, \exp }$ which is the expected mean compressive strength of concrete at the age of 28 days, see Eq. (41).

$f_{\mathrm{cm}, 28, \exp }=\mathrm{A} \cdot \frac{\chi_{\mathrm{c}}^{{ }^{\mathrm{n}_{\chi}}} \cdot p^{\mathrm{n}_{\mathrm{p}}}}{(1+x)^{\mathrm{n}_{\mathrm{x}}}} \cdot(1-l)^{\mathrm{n}_{l}}$

where:

$f_{\mathrm{cm}, 28, \exp }\left[\mathrm{N} / \mathrm{mm}^{2}\right]$ is the target mean compressive strength measured on cube specimens after 28 days standard curing,

$\mathrm{A}$ is the experiment constant, for CEM II/A-M (V-LL) A=342.302,

$\chi_{\mathrm{c}}$ is the cement volumetric ratio in the paste powder, $\mathrm{n}_{\chi}$ is the exponent of $\chi_{c}$, for CEM II/A-M (V-LL) $\mathrm{n}_{\chi}=1.711$,

$p$ is the paste volumetric ratio in the concrete, $\mathrm{n}_{p}$ is the exponent of $p$, for CEM II/A-M (V-LL) $\mathrm{n}_{p}=-0.240$,

$x$ is the liquid-paste volume factor in the paste, $\mathrm{n}_{x}$ is the exponent of $(1+x)$, for CEM II/A-M (V-LL) $\mathrm{n}_{x}=2.355$

$l$ is the air volumetric ratio in the concrete, $\mathrm{n}_{l}$ is the exponent of $l$, for CEM II/A-M (V-LL) $\mathrm{n}_{l}=3.75$.
For the experiential correlations used for consistence Eq. (39)

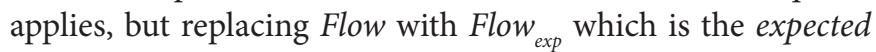
mean flow value of the fresh concrete mix, see Eq. (42).

Flow $_{\text {exp }}[\mathrm{mm}]=\left(1+\mathrm{f}_{1, \mathrm{AD}} \cdot \lambda_{\mathrm{AD}}\right) \cdot \mathrm{f}_{2, \mathrm{AD}} \cdot \mathrm{A} \cdot \frac{\left(\frac{x}{f_{z}}\right)^{\mathrm{n}_{\mathrm{x}}}}{\left(1+\frac{a \cdot f_{\mathrm{a}}}{z \cdot f_{\mathrm{z}}}\right)^{\mathrm{n}_{\mathrm{f}}} \cdot\left(1+\frac{a}{z}\right)^{\mathrm{n}_{\mathrm{a}}}}$

where:

Flow $_{\text {exp }}$ is the expected mean flow value $[\mathrm{mm}]$ of the concrete mix by flow table,

$\lambda_{\mathrm{AD}}$ is the dose of admixture in the volumetric ratio of paste powder (concrete composition content indicator),

$\mathrm{f}_{1, \mathrm{AD}}$ is the dose factor of the admixture (for specific values of MRWR see Table 15),

$\mathrm{f}_{2, \mathrm{AD}}$ is the factor typical of the material of the admixture (for specific values of MRWR see Table 15),

A is the experimental constant, in this case $A=39386.8$,

$\mathrm{n}_{\mathrm{x}}, \mathrm{n}_{\mathrm{f}}$ and $\mathrm{n}_{\mathrm{a}}$ are exponents, with observed values as follows: $\mathrm{n}_{\mathrm{x}}=0.288, \mathrm{n}_{\mathrm{f}}=1.208$ and $\mathrm{n}_{\mathrm{a}}=0.319$,

$f_{\mathrm{z}}$ is the volumetric specific surface area of the paste powder $\left[\mathrm{m}^{2} / \mathrm{m}^{3}\right]$, in this case $f_{\mathrm{z}} \approx \chi_{\mathrm{c}} f_{\mathrm{c}}+\left(1-\chi_{\mathrm{c}}\right) f_{\mathrm{K}},\left(f_{\mathrm{c}}\right.$ and $f_{\mathrm{K}}$ according to Table 13),

$f_{\mathrm{a}}$ is the volumetric specific surface area of the aggregate $\left[\mathrm{m}^{2} /\right.$ $\mathrm{m}^{3}$ ], in this case $f_{\mathrm{a}}$ according to Table 13,

$z$ is the volumetric ratio of paste powder in the concrete $(z=p /[1+x])$, $a$ is the volumetric ratio of aggregate in the concrete $(a=1-l-p)$.

Finally, the correlations to be considered due to the restriction $w / c \leq 0.55$ can be given by Eq. (43).

$x \approx \chi_{c} \cdot\left(\frac{w}{c}-s w_{c}\right) \frac{\rho_{c}}{\rho_{f}}$

where $\rho_{f}$ is the mean density of the liquid constituents in the concrete (mostly water).

Substituting the data in Eq. (43) $\rho_{c}$ and $s w_{c}$ from Table 13 and $\rho_{f}=1000 \mathrm{~kg} / \mathrm{m}^{3}$ gives Eq. (44).

$x \leq \chi_{c} \cdot\left(0.55-s w_{c}\right) \frac{\rho_{c}}{\rho_{f}}=\chi_{c} \cdot(0.55-0.0151) \frac{3000}{1000}=1.6047 \cdot \chi_{c}$

6.4 Determining the concrete composition content indicators required to fulfil the criteria, and determining the possible mix compositions by solving the system of material balance equations

Concrete mixes are determined by five linearly independent content indicators, but there are two estimate formulae, Eqs. (41) and (42), and furthermore, one of the content indicators is assumed to have a value of $l=0.020$ (therefore with an air content of 20 litres $/ \mathrm{m}^{3}$ ), so the number of concrete composition content indicators that may be freely selected is reduced to two, and even between $x$ and $\chi_{c}$ there is the restriction given by Eq. (44). It is practical to freely select the values of $p$ and $\chi_{c}$, and to calculate - from the interactions of Eqs. (41), (42) and (44) - the possible content indicators $x$ and $\lambda_{A D}$. After the five content indicators have been determined in this way, they also provide the structural vector 
on the right hand side of Eq. (40), from which the matrix equation can be solved to find the mix composition vector. The calculations in the example have been performed for paste contents of 280 and $300 \mathrm{l} / \mathrm{m}^{3}$ ( $p=0.280$ and $p=0.300$ ) and for addition contents of almost zero and $15 \mathrm{~V} \%\left(\chi_{c}=0.850\right.$ and $\left.\chi_{c}=0.972 \ldots 0.976\right)$ and the results of the calculations are presented in Table 16.

\subsection{Discussion}

Of the mix compositions presented in Table 16, mixes no. 1, 6 and 7 fulfil all the requirements, including those for body density - which are too strict in the opinion of the author of the present paper. The data in Table 16 show that there is not much to be gained by increasing the paste content in a given concrete and by targeting the upper limit within the strength class, as this involves an increase in the dose of cement, and furthermore the dose of water reducing admixture also needs to be increased. The mix that best meets the requirements is no. 1, in the opinion of the author of the present paper, even though mix no. 1 also has the blemish in that according to Table 15, the industrial observations were in the range $\lambda_{A D}<0.030$, while here one can see $\lambda_{A D}=0.034$, which is an extrapolated value. It would be possible to make adjustments by amending the flow value criterion, but it is not worthwhile, as even if $\lambda_{A D}=0.030$, the estimated flow value is $\sim 508 \mathrm{~mm}$, which is a negligible difference to the designed $520 \mathrm{~mm}$.

\section{Present and future tasks in concrete engineering}

Concrete engineering in the last few decades has witnessed the appearance of newer and newer types of cements and admixtures, and it is impossible for standard methods to keep up with technical developments when it comes to describing the effects of the new materials. This necessitated a new systematic and harmonised examination of the effects of concrete constituents, in order to gain a deeper insight into their effects. This is not just in the interest of the cement producers or the companies that distribute the admixtures, but also in the interest of concrete mixing plants. Research is already underway in many institutes separately. Author of the present paper has no doubt about the commitment of ÉMI Nonprofit Ltd in this sense: the research is ongoing in cooperation with scientific institutions and with smaller and larger concrete mixing plants, which have the objective of optimising concrete compositions and of improving the advancement of the technical culture in concrete mixing plants.

\section{Acknowledgments}

The author owes his gratitude to the managers of the Augusztin Concrete Manufacturing Company and of ÉMI Nonprofit Ltd for providing the ideal circumstances for preparing this work, and to DDCM Ltd and BASF Hungary Ltd for generously providing some of the research materials. Colleagues who need to receive thanks in person are: Dr. Tamás Bánky, Dr. Károly Kovács, Dr. Károly Matolcsy, Mrs. Éva Horváth Török and Mr. Sándor Boros for their support and countless well-intentioned remarks. Special thanks to Mr. Ferenc Spránitz for his invaluable advice, to Mr. Bálint Augusztin Jr. and Mr. Attila Bohák for the especially valuable and conscientious work they did in conducting the experiments and in developing the concrete test protocol. The author is respectfully grateful to his former teachers Dr. János Ujhelyi, Dr. György Balázs, Dr. Attila Erdélyi, Dr. Kálmán Szalai, Dr. Tibor Kausay and many other people whose life achievements set a high standard for future generations of engineers.

\section{References}

[1] Alexanderson, J.: Design of concrete mixes. Materials and Structures, Vol. 4, No. 4, July, 1971. pp. 203-212. http://dx.doi.org/10.1007/BF02478946

[2] Ujhelyi, J.: A beton struktúrájának és nyomószilárdságának tervezése. Doktori értekezés. Magyar Tudományos Akadémia 1989. augusztus.

[3] Spránitz, F.: „Érdemes-e küszködni az NT betonokkal? 4. rész - avagy milyen neműek a nagy teljesítőképességü (NT) betonok?", Beton, XVII. évf. 1. szám, 2009. január, pp. 3-7.

[4] Spránitz, F.: „Érdemes-e küszködni az NT betonokkal? 5. rész - avagy milyen nemüek a nagy teljesítőképességü (NT) betonok?", Beton, XVII. évf. 2. szám, 2009. február, pp. 3-6.

[5] Toutou, Z. - Roussel, N.: Multi Scale Experimental Study of Concrete Rheology: From Water Scale to Gravel Scale. Materials and Structures, Vol. 39, No. 2, March, 2006. pp. 189-199. http://dx.doi.org/10.1617/s11527-005-9047-y

[6] Pekár, Gy.: Simple basic model for concrete and its application. 2. Factors that infl uence compressive strength and drying shrinkage Épitöanyag, 65. évf. 3. szám (2013), pp. 76-84. http://dx.doi.org/10.14382/epitoanyagjsbcm.2013.15

[7] Kausay, T.: Beton adalékanyagok szemmegoszlási jellemzőinek számítása grafoanalitikus módon. Vasbetonépítés. VI. évf. 1. szám 2004. pp. 3-11.

[8] Pekár, Gy.: Simple basic model for concrete and its application. 1. Content indicators of concrete mixtures and mixing plant observations. Épitöanyag, 65. évf. 2. szám (2013), pp. 52-60. http://dx.doi.org/10.14382/epitoanyagjsbcm.2013.12

[9] MSZ EN 206-1:2002, MSZ EN 206-1:2000/A1:2004, MSZ EN 206-1:2000/ A2:2005 Concrete. Part 1: Technical conditions, performance, preparation and compliance.

[10] Palotás, L. - Balázs, L.: Mérnöki szerkezetek anyagtana III. Akadémiai Kiadó, Budapest 1980.

[11] Arany, P. - Nehme, S. G. - Fehérvári, S.: Építőanyagok I. (BScBMEEOMAT12) Laboratóriumi gyakorlati segédlet. Betontervezés. BME Épitőanyagok és Mérnökgeológia Tanszék, 2008. április 7.

\section{Ref.:}

Gyula Pekár: Simple basic model for concrete and its application Part 3. Factors affecting consistency, material balance equations and mix design

Építőanyag, 65. évf. 4. szám (2013), 118-126. p. http://dx.doi.org/10.14382/epitoanyag-jsbcm.2013.22

\section{Betonkeverékek egyszerűsített alapmodellje és} alkalmazása

3. rész: Konzisztenciát befolyásoló tényezők, anyagmérleg egyenletek, összetételek tervezése

A gyártóüzemi megfigyelések során a konzisztenciára vonatkozóan is számos érdekes kérdés merült fel. A szerzó véleménye szerint igazán értékelhetố adathalmazt éppen a gyártóüzemekben (illetve a transzportbeton kiszállítási helyszínein) végzett vizsgálatokkal nyerhetünk. Mindazonáltal a statisztikai jellemző́k a konzisztencia tekintetében korántsem igazolnak olyan szoros kapcsolatot, mint a szilárdság vagy az alakváltozás esetén, ezért a kelló óvatosság indokolt, bár az óvatosság sosem jelentheti azt, hogy legyintve mondjunk le bizonyos következtetések levonásáról. A betonösszetételi (strukturális) állapotjelzók bevezetése hasznos lehet a friss (és megszilárdult) betonkeverékek összetételének tervezése során is, amennyiben ismerjük, vagy kísérleti úton meghatározzuk a betonösszetételi állapotjelzốk és a friss és megszilárdult beton tulajdonságai közötti összefüggéseket, és alkalmazzuk a betonkeverékek anyagmérleg egyenleteit. A cikksorozat befejezô része ezeket a kérdéseket mutatja be. 